Article

\title{
Effects of alkaline additives on the formation of lactic acid in sorbitol hydrogenolysis over $\mathrm{Ni} / \mathrm{C}$ catalyst
}

\author{
Junjie Zhang a,b, Fang Lu a,\#, Weiqiang Yu a, Rui Lu a,b, Jie Xu ${ }^{a, *}$ \\ a State Key Laboratory of Catalysis, Dalian Institute of Chemical Physics, Chinese Academy of Sciences, Dalian National Laboratory for Clean Energy, \\ Dalian 116023, Liaoning, China \\ b University of Chinese Academy of Sciences, Beijing 100049, China
}

\section{A R T I C L E I N F O}

\section{Article history:}

Received 28 August 2015

Accepted 24 September 2015

Published 5 January 2016

Keywords:

Lactic acid

Alkali

Sorbitol

Catalytic hydrogenolysis

Nickel catalyst

\begin{abstract}
A B S T R A C T
Lactic acid is produced as a major byproduct during sorbitol hydrogenolysis under alkaline conditions. We investigated the effects of two different alkaline additives, $\mathrm{Ca}(\mathrm{OH})_{2}$ and $\mathrm{La}(\mathrm{OH})_{3}$, on lactic acid formation during sorbitol hydrogenolysis over $\mathrm{Ni} / \mathrm{C}$ catalyst. In the case of $\mathrm{Ca}(\mathrm{OH})_{2}$, the selectivity of lactic acid was $8.9 \%$. In contrast, the inclusion of $\mathrm{La}(\mathrm{OH})_{3}$ resulted in a sorbitol conversion of $99 \%$ with only trace quantities of lactic acid being detected. In addition, the total selectivity towards the $\mathrm{C} 2$ and $\mathrm{C} 4$ products increased from $20.0 \%$ to $24.5 \%$ going from $\mathrm{Ca}(\mathrm{OH})_{2}$ to $\mathrm{La}(\mathrm{OH})_{3}$. These results therefore indicated that $\mathrm{La}(\mathrm{OH})_{3}$ could be used as an efficient alkaline additive to enhance the conversion of sorbitol. Pyruvic aldehyde, which is formed as an intermediate during sorbitol hydrogenolysis, can be converted to both 1,2-propylene glycol and lactic acid by hydrogenation and rearrangement reactions, respectively. Notably, these two reactions are competitive. When $\mathrm{Ca}(\mathrm{OH})_{2}$ was used as an additive for sorbitol hydrogenolysis, both the hydrogenation and rearrangement reactions occurred. In contrast, the use of $\mathrm{La}(\mathrm{OH})_{3}$ favored the hydrogenation reaction, with only trace quantities of lactic acid being formed.
\end{abstract}

(c) 2016, Dalian Institute of Chemical Physics, Chinese Academy of Sciences. Published by Elsevier B.V. All rights reserved.

\section{Introduction}

Sugar alcohols, such as sorbitol and xylitol, are attractive platform chemicals because they can be readily produced by the hydrogenation of sugars, which are available in large quantities from natural sources [1-3]. Furthermore, sugar alcohols can be converted to ethylene glycol (EG) and 1,2-propylene glycol (1,2-PG) [4-6]. EG and 1,2-PG are important commodity chemicals that are widely used as starting materials for the preparation of polyesters. The main manufacturing route currently used for the industrial production of EG and PG is based on the two-step conversion of petroleum-derived ethylene and propylene feedstocks. The development of a direct method for the conversion of sugar alcohols to EG and PG is therefore highly desired as an energy-efficient and environmental friendly alternative to the existing procedures in terms of utilizing renewable resources [7-9].

The mechanism for sugar alcohols hydrogenolysis is generally believed to involve two key steps $[10,11]$. According to the first step of this mechanism, the polyol substrates would be dehydrogenated over a metal catalyst under alkaline conditions to give the corresponding carbonyl intermediates. The subsequent cleavage of the $\mathrm{C}-\mathrm{C}$ bonds in these intermediates under basic conditions would give the EG and PG products, most like-

\footnotetext{
* Corresponding author. Tel/Fax: +86-411-84379245; E-mail: xujie@dicp.ac.cn

\# Corresponding author. Tel/Fax: +86-411-84379245; E-mail: lufang@dicp.ac.cn

This work was supported by the National Natural Science Foundation of China $(21203183,21233008,21473188)$.

DOI: 10.1016/S1872-2067(15)60976-7 | http://www.sciencedirect.com/science/journal/18722067 | Chin. J. Catal., Vol. 37, No. 1, January 2016
} 
ly via a retro-aldol condensation. Sugar alcohols hydrogenolysis proceeds much more efficiently under basic conditions, which appear to facilitate the dehydrogenation and $\mathrm{C}-\mathrm{C}$ bond cleavage reactions. Several inorganic bases, including $\mathrm{Ca}(\mathrm{OH})_{2}$ [12-14], $\mathrm{KOH}$ [15], $\mathrm{NaOH}$ [16], $\mathrm{CaO}$ [17-19], and $\mathrm{Ba}(\mathrm{OH})_{2}$ [20], have been investigated as additives for the hydrogenolysis of sorbitol in terms of their effects on the conversion of sorbitol and the selectivity of the products. In general, the results of these studies showed that the addition of an inorganic base favored the formation of glycols compared with the use of neutral conditions. However, the addition of an inorganic base to these hydrogenolysis reactions typically results in the formation of lactic acid as a major byproduct. Liu et al. [11] evaluated the effects of several different inorganic bases, including $\mathrm{CaCO}_{3}$, $\mathrm{Mg}(\mathrm{OH})_{2}$, and $\mathrm{Ca}(\mathrm{OH})_{2}$, on xylitol hydrogenolysis and found that the nature of the base had a significant effect on the selectivity towards lactic acid, as well as the activity of the reaction. The selectivity towards lactic acid increased as the $\mathrm{pH}$ of the reaction medium increased. In a later study, Xia et al. [21] reported that the conversion of xylitol and selectivity towards lactic acid increased as the amount of $\mathrm{Ca}(\mathrm{OH})_{2}$ added to the reaction increased. Unfortunately, lactic acid formation could be problematic for sugar alcohols hydrogenolysis. For example, the presence of lactic acid would result in the consumption of the alkaline material present in the reaction mixture, which would suppress the conversion of the sugar alcohols. Furthermore, the presence of lactic acid could complicate the analysis of the product mixture. To address these limitations, we wanted to develop a deeper understanding of the hydrogenolysis process. For example, we intended to understand why the addition of an inorganic base led to lactic acid formation. We also wanted to identify the pathway responsible for lactic acid formation. Based on this improved understanding, we then wanted to develop a new process capable of achieving high levels of sugar alcohols conversion with only trace quantities of lactic acid.

Supported Ni systems have been reported as effective catalysts for sorbitol hydrogenolysis [22]. Furthermore, the introduction of a La species into these catalysts led to an increase in the conversion of xylitol, as well as an increase in the selectivity towards glycols [23]. $\mathrm{La}(\mathrm{OH})_{3}$ has been used as a heterogeneous alkaline catalyst for the Knoevenagel reaction [24] and has also been used as an additive for the conversion of cellulose [25]. In this work, we evaluated the effects of two different alkaline additives, $\mathrm{Ca}(\mathrm{OH})_{2}$ and $\mathrm{La}(\mathrm{OH})_{3}$, on the formation of lactic acid during sorbitol hydrogenolysis over $\mathrm{Ni} / \mathrm{C}$ catalyst. We also studied the reactions of pyruvic aldehyde over Ni/C catalyst in the presence of $\mathrm{Ca}(\mathrm{OH})_{2}$ and $\mathrm{La}(\mathrm{OH})_{3}$, with the aim of exploring the pathway as plausible mechanism for lactic acid formation.

\section{Experimental}

\subsection{Materials}

All of the chemicals were purchased at analytic grade and used as received. $\mathrm{Ni}\left(\mathrm{NO}_{3}\right)_{2} \cdot 6 \mathrm{H}_{2} \mathrm{O}, \mathrm{NaOH}, \mathrm{Ca}(\mathrm{OH})_{2}$, and lactic acid were obtained from Tianjin Kemiou Chemical Reagent Co., Ltd. Glycerol was purchased from Sinopharm Chemical Reagent Co., Ltd. $\mathrm{La}(\mathrm{OH})_{3}(99.9 \%)$ was obtained from Aladdin Industrial Inc. Sorbitol (98\%) and pyruvic aldehyde (35\%-45\%) were obtained from Alfa Aesar (Tianjin, China). Activated carbon (80-100 mesh, BET surface area $1318 \mathrm{~m}^{2} / \mathrm{g}$ ) was purchased from Beijing Guanghua Timber Mill.

\subsection{Catalyst preparation}

The $10 \mathrm{wt} \% \mathrm{Ni} / \mathrm{C}$ catalyst was prepared according to a modified incipient wetness impregnation method. Briefly, activated carbon ( $1.0 \mathrm{~g}$ ) was added to a aqueous solution of $\mathrm{Ni}\left(\mathrm{NO}_{3}\right)_{2}(1.2 \mathrm{~mol} / \mathrm{L}, 1.6 \mathrm{~mL})$ under stirring, and the resulting solution was sonicated for $0.5 \mathrm{~h}$. The mixture was then aged for $24 \mathrm{~h}$ at ambient temperature before being dried at $383 \mathrm{~K}$ for 12 h. The resulting catalysts were then reduced with $\mathrm{H}_{2}$ at $723 \mathrm{~K}$ for $3 \mathrm{~h}$ prior to being used in the hydrogenolysis reactions.

\subsection{Catalytic reactions and product analysis}

The catalytic reactions were carried out in a $50-\mathrm{mL}$ stainless steel autoclave. For a typical run, the reactor was charged with a $10 \mathrm{wt} \%$ solution of sorbitol in water $(20 \mathrm{~mL})$, the pre-reduced catalyst $(0.3 \mathrm{~g})$, and the required amount of the additive (i.e., $0.18 \mathrm{~g}$ of $\mathrm{Ca}(\mathrm{OH})_{2}$ or $0.3 \mathrm{~g}$ of $\left.\mathrm{La}(\mathrm{OH})_{3}\right)$. The reactor was then purged several times with $\mathrm{H}_{2}$ to remove any air and pressurized up to 5.0 MPa with $\mathrm{H}_{2}$. The reactor was then heated to 493 $\mathrm{K}$ and stirred at $1000 \mathrm{r} / \mathrm{min}$ for $1 \mathrm{~h}$.

The products of the reaction were analyzed by gas chromatography using an Agilent 7890A gas chromatograph equipped with a 19091j-323 capillary column and a flame ionization detector. The starting materials and products were analyzed by HPLC on a Waters e2695 separations module equipped with a refractive index detector (Waters 2414) and an UV/visible detector (Waters 2489). All of the samples were acidified $(\mathrm{pH}=2$ ) using a aqueous $\mathrm{H}_{2} \mathrm{SO}_{4}$ solution ( $2 \mathrm{~mol} / \mathrm{L}$ ) prior to being analyzed by HPLC. The HPLC system was equipped with an OA-1000 column, which was eluted with an $0.2 \mathrm{wt} \%$ aqueous $\mathrm{H}_{2} \mathrm{SO}_{4}$ solution as the mobile phase at a flow rate of 0.5 $\mathrm{mL} / \mathrm{min}$.

\section{Results and discussion}

\subsection{Effects of types and amount of alkaline additives on catalytic hydrogenolysis of sorbitol}

Sorbitol hydrogenolysis was examined over $\mathrm{Ni} / \mathrm{C}$ catalyst in the absence and presence of three different inorganic bases to determine the impact of these additives on the conversion and selectivity of the reaction (Table 1 ). $\mathrm{NaOH}, \mathrm{Ca}(\mathrm{OH})_{2}$, and $\mathrm{La}(\mathrm{OH})_{3}$ were used as the additives in this study based on their different water solubility properties. When Ni/C (Table 1, entry 1) was used as the catalyst in the absence of any additive, the sorbitol conversion was only $19.2 \%$. The addition of $\mathrm{NaOH}$ (Table 1, entry 2) led to a significant increase in the sorbitol conversion to $73.8 \%$. However, much greater increases were 
Table 1

Effects of the different alkaline additives on the conversion and selectivity for sorbitol hydrogenolysis over Ni/C catalyst.

\begin{tabular}{|c|c|c|c|c|c|c|c|c|c|c|c|}
\hline \multirow{2}{*}{ Entry } & \multirow{2}{*}{ Additive } & \multirow{2}{*}{$\begin{array}{c}\text { Amount of } \mathrm{OH}^{-} \\
(\mathrm{mmol})\end{array}$} & \multirow{2}{*}{$\begin{array}{c}\text { Conversion } \\
(\%)\end{array}$} & \multicolumn{8}{|c|}{ Selectivity a (\%) } \\
\hline & & & & EG & 1,2-PG & Glycerol & $\mathrm{BG}^{\mathrm{b}}$ & Lactic acid & Glycolic acid & Acetic acid & Others $^{c}$ \\
\hline 1 & - & - & 19.2 & 2.9 & 1.4 & 6.0 & 2.2 & - & - & - & 87.5 \\
\hline 2 & $\mathrm{NaOH}$ & 4.74 & 73.8 & 16.1 & 21.6 & 6.7 & 3.2 & 15.1 & 0.3 & 2.6 & 34.4 \\
\hline 3 & $\mathrm{Ca}(\mathrm{OH})_{2}$ & 0.79 & 68.8 & 10.9 & 14.1 & 20.0 & 3.0 & 2.0 & 0.1 & 0.3 & 49.5 \\
\hline 4 & $\mathrm{Ca}(\mathrm{OH})_{2}$ & 1.58 & 81.3 & 12.4 & 20.0 & 14.7 & 4.0 & 3.7 & 0.2 & 0.5 & 44.6 \\
\hline 5 & $\mathrm{Ca}(\mathrm{OH})_{2}$ & 4.74 & 100 & 16.6 & 30.0 & 7.1 & 4.9 & 8.9 & 0.2 & 0.7 & 31.5 \\
\hline 6 & $\mathrm{Ca}(\mathrm{OH})_{2}$ & 7.90 & 100 & 15.6 & 33.1 & 1.1 & 4.4 & 10.3 & 0.5 & 1.2 & 33.8 \\
\hline 7 & $\mathrm{Ca}(\mathrm{OH})_{2}$ & 11.06 & 100 & 12.8 & 30.3 & 0.5 & 4.0 & 11.7 & 0.7 & 1.2 & 38.9 \\
\hline 8 & $\mathrm{La}(\mathrm{OH})_{3}$ & 0.02 & 29.1 & 6.9 & 5.7 & 16.8 & 4.6 & - & - & - & 66.0 \\
\hline 9 & $\mathrm{La}(\mathrm{OH})_{3}$ & 0.08 & 99.0 & 14.5 & 14.3 & 9.2 & 5.2 & trace & - & - & 56.8 \\
\hline 10 & $\mathrm{La}(\mathrm{OH})_{3}$ & 0.16 & 99.0 & 14.2 & 15.3 & 8.6 & 5.7 & trace & - & - & 56.2 \\
\hline 11 & $\mathrm{La}(\mathrm{OH})_{3}$ & 0.79 & 99.0 & 15.6 & 17.8 & 13.2 & 7.3 & trace & - & - & 46.1 \\
\hline 12 & $\mathrm{La}(\mathrm{OH})_{3}$ & 1.58 & 99.0 & 15.7 & 19.2 & 16.8 & 7.8 & trace & - & - & 40.5 \\
\hline 13 & $\mathrm{La}(\mathrm{OH})_{3}$ & 4.74 & 99.0 & 15.9 & 21.5 & 13.7 & 8.0 & 0.1 & - & - & 40.8 \\
\hline 14 & $\mathrm{La}(\mathrm{OH})_{3}$ & 7.90 & 100 & 15.5 & 23.6 & 9.6 & 9.0 & 0.2 & - & - & 42.1 \\
\hline 15 & $\mathrm{La}(\mathrm{OH})_{3}$ & 11.06 & 100 & 13.9 & 19.6 & 4.3 & 7.3 & 0.3 & - & - & 54.6 \\
\hline 16 & $\mathrm{La}\left(\mathrm{NO}_{3}\right)_{3}$ & $1.58^{\mathrm{d}}$ & 15.3 & - & - & 5.7 & - & 16.5 & 10.1 & 0.8 & 66.9 \\
\hline
\end{tabular}

Reaction conditions: $10 \% \mathrm{Ni} / \mathrm{C} 0.3 \mathrm{~g}, 10 \mathrm{wt} \%$ aqueous sorbitol solution $20 \mathrm{~mL}, 493 \mathrm{~K}, \mathrm{H}_{2}$ pressure (RT) $5 \mathrm{MPa}, 1 \mathrm{~h}$.

$\mathrm{EG}=$ ethylene glycol, 1,2-PG = 1,2-propylene glycol.

a $\mathrm{C}$-based selectivity.

b BG includes 2,3-butanediol, 1,2-butanediol, 1,4-butanediol, and 1,2,4-butanetriol.

c Others include methane, methanol, ethanol, and some unidentified.

d $1.58 \mathrm{mmol} \mathrm{La}\left(\mathrm{NO}_{3}\right)_{3}$.

observed following the addition of $\mathrm{Ca}(\mathrm{OH})_{2}$ (Table 1, entry 5) or $\mathrm{La}(\mathrm{OH})_{3}$ (Table 1, entry 13), which gave sorbitol conversions of $100 \%$ and $99 \%$, respectively. With regard to the selectivities of these reactions, the total selectivity towards EG (C2 product) and the $\mathrm{BG}$ products ( $\mathrm{C} 4$ products) was only $5.1 \%$ in the absence of any additive (Table 1, entry 1). In contrast, the total selectivity values for EG and BG were $20.0 \%$ and $24.5 \%$ following the addition of $7.90 \mathrm{mmol} \mathrm{OH}^{-}$for $\mathrm{Ca}(\mathrm{OH})_{2}$ (Table 1 , entry 6) and $\mathrm{La}(\mathrm{OH})_{3}$ (Table 1, entry 14) to the hydrogenolysis reaction, respectively. These results therefore indicated that addition of an alkaline additive led to a significant improvement in the sorbitol conversion and selectivity of the hydrogenolysis reaction. Furthermore, these results were consistent with those from several previous reports $[11,20]$. Notably, the $\mathrm{La}(\mathrm{OH})_{3}$ additive favored the cleavage of the $\mathrm{C} 2-\mathrm{C} 3$ bond in sorbitol.

Consideration of the selectivity of the reaction towards lactic acid revealed that there were significant differences between the different additives. For example, no lactic acid was detected when the reaction was conducted in the presence of the $\mathrm{Ni} / \mathrm{C}$ catalyst without additive (Table 1 , entry 1 ). When $\mathrm{NaOH}$ (Table 1, entry 2) or $\mathrm{Ca}(\mathrm{OH})_{2}$ (Table 1, entry 5) was used as the additive, the selectivities of the reaction towards lactic acid were $15.1 \%$ and $8.9 \%$, respectively. However, when $\mathrm{La}(\mathrm{OH})_{3}$ (Table 1, entry 13) was used as an additive, the selectivity towards lactic acid was only $0.1 \%$. For $\mathrm{Ca}(\mathrm{OH})_{2}$ and $\mathrm{La}(\mathrm{OH})_{3}$, the selectivities of the reaction towards $\mathrm{C} 3$ products (i.e., 1,2-PG, glycerol, and lactic acid) were $46.0 \%$ and $35.3 \%$, respectively. These results therefore indicated that the addition of $\mathrm{Ca}(\mathrm{OH})_{2}$ to the hydrogenolysis reaction favored the cleavage of the C3-C4 bond of sorbitol. However, this increase in the C3-C4 bond cleavage products led to higher levels of lactic acid instead of the $\mathrm{C} 3$ polyols.
We subsequently proceeded to investigate the effects of different amounts of alkali on lactic acid formation using $\mathrm{Ca}(\mathrm{OH})_{2}$ and $\mathrm{La}(\mathrm{OH})_{3}$ as the additives; the results are shown in Table 1 . When $\mathrm{Ca}(\mathrm{OH})_{2}$ was used as an additive (Table 1, entries 3-7), the conversion of sorbitol increased as the amount of $\mathrm{Ca}(\mathrm{OH})_{2}$ added to the reaction increased. For example, the use of 0.79 mmol $\mathrm{OH}^{-}$led to a sorbitol conversion of $68.8 \%$ (Table 1, entry 3 ), whilst the use of $4.74 \mathrm{mmol} \mathrm{OH}^{-}$led to a much higher sorbitol conversion of $100 \%$ (Table 1, entry 5). With regards to the production of lactic acid, the selectivity increased as the amount of $\mathrm{Ca}(\mathrm{OH})_{2}$ added to the reaction increased, reaching $11.7 \%$ with $11.06 \mathrm{mmol} \mathrm{OH}^{-}$(Table 1, entry 7). Increasing the amount of $\mathrm{Ca}(\mathrm{OH})_{2}$ initially led to a gradual increase in the selectivity of the reaction towards 1,2-PG, with further increase leading to a gradual decrease in 1,2-PG. Furthermore, the selectivity of glycerol decreased as the amount of $\mathrm{Ca}(\mathrm{OH})_{2}$ increased. When $\mathrm{La}(\mathrm{OH})_{3}$ was used as the additive, the sorbitol conversion

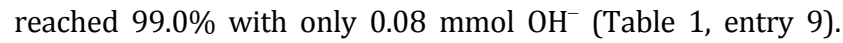
Notably, these conditions afforded only $0.3 \%$ lactic acid up to $11.06 \mathrm{mmol} \mathrm{OH}^{-}$(Table 1, entry 15). The selectivity of the reaction towards 1,2-PG and glycerol initially increased and then decreased with further increase in the amount of $\mathrm{La}(\mathrm{OH})_{3}$. Based on these above results, it was clear that the nature and the amount of the alkaline additive had a significant impact on lactic acid formation. In the case of $\mathrm{Ca}(\mathrm{OH})_{2}$, the selectivity towards lactic acid was dependent on the amount of the alkaline additive. However, the use of $\mathrm{La}(\mathrm{OH})_{3}$ led to only trace quantities of lactic acid.

We wanted to develop a deeper understanding of the differences between these additives for the conversion of sorbitol. We noticed that the $\mathrm{pH}$ of the hydrogenolysis reaction mixture changed before and after the reaction with the $\mathrm{Ca}(\mathrm{OH})_{2}$ additive. The $\mathrm{pH}$ value was 12 before the reaction and decreased to 
7 after the reaction. However, when $\mathrm{La}(\mathrm{OH})_{3}$ was used as an additive, the $\mathrm{pH}$ of the reaction mixture was around 7 both before and after the reaction. It is well known that $\mathrm{Ca}(\mathrm{OH})_{2}$ is only partially water-soluble and that its solubility in water at room temperature is $0.165 \mathrm{~g} / 100 \mathrm{~mL}$. In contrast, $\mathrm{La}(\mathrm{OH})_{3}$ is completely insoluble in water at room temperature. The basic environment provided by $\mathrm{Ca}(\mathrm{OH})_{2}$ would therefore promote lactic acid formation, which would subsequently neutralize and consume the remaining $\mathrm{Ca}(\mathrm{OH})_{2}$.

To further explore the nature of the interactions between lactic acid and the alkaline additives, we investigated the hydrogenation of lactic acid in the presence of $\mathrm{Ca}(\mathrm{OH})_{2}$ and $\mathrm{La}(\mathrm{OH})_{3}$. The lactic acid remained unchanged in the presence of $\mathrm{Ca}(\mathrm{OH})_{2}$, whilst it was hydrogenated to give 1,2-PG with a conversion of $67.9 \%$ in the presence of $\mathrm{La}(\mathrm{OH}) 3$. It has been reported that lactic acid can be hydrogenated to 1,2-PG under acidic and neutral conditions [26]. In the presence of $\mathrm{Ca}(\mathrm{OH})_{2}$, lactic acid would exist as the corresponding calcium lactate salt, which would be very stable in the solution [27]. These results also indicated that lactic acid could neutralize $\mathrm{Ca}(\mathrm{OH})_{2}$ but not $\mathrm{La}(\mathrm{OH})_{3}$. $\mathrm{Ca}(\mathrm{OH})_{2}$ could therefore be consumed by lactic acid. It has also been reported that the first step in the dehydrogenation of sorbitol could be promoted by an alkaline additive. The continuous consumption of the alkaline additive would consequently suppress the conversion of sorbitol. A large amount of $\mathrm{Ca}(\mathrm{OH})_{2}$ would therefore be required to achieve the complete conversion of sorbitol. Furthermore, the selectivity towards lactic acid increased as the amount of $\mathrm{Ca}(\mathrm{OH})_{2}$ added to the reaction increased. In contrast, the $\mathrm{La}(\mathrm{OH})_{3}$ additive could not be consumed in the same way, meaning that a much smaller amount of $\mathrm{La}(\mathrm{OH})_{3}$ could be used to achieve the complete conversion of sorbitol. Given that lactic acid can be hydrogenated to give 1,2-PG in the presence of $\mathrm{La}(\mathrm{OH})_{3}$, it seems unlikely that the trace quantities of lactic acid formed during this reaction could be attributed to the consumption of lactic acid. Based on our result for sorbitol hydrogenolysis in the presence of $\mathrm{La}(\mathrm{OH})_{3}$ (Table 1, entry 13) and the conversion of lactic acid, we calculated the total selectivity towards lactic acid, which was much lower than that of lactic acid $(8.9 \%)$ in the presence of $\mathrm{Ca}(\mathrm{OH})_{2}$ (Table 1, entry 5) under the same conditions. To

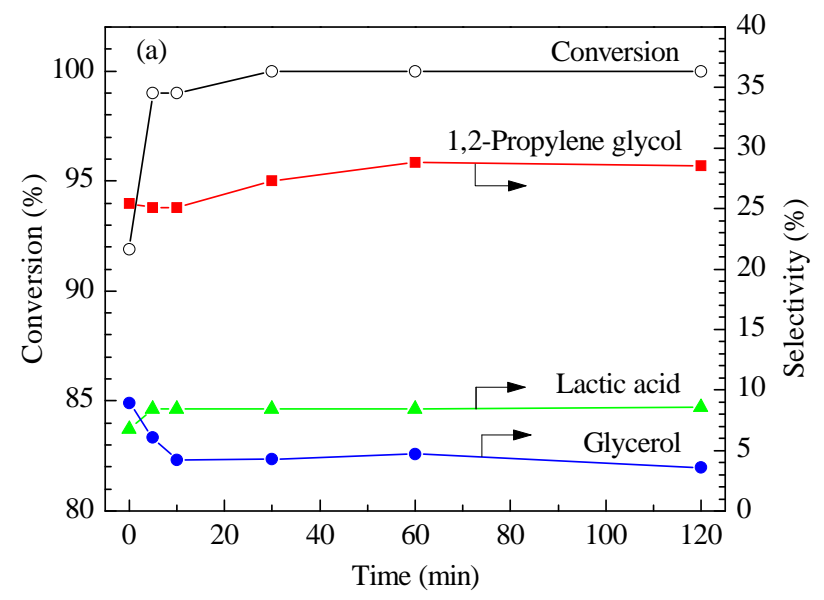

develop a better understanding of the role of $\mathrm{La}^{3+}$ in this reaction, we evaluated the use of $\mathrm{La}\left(\mathrm{NO}_{3}\right)_{3}$ (Table 1, entry 16) as an additive, which gave a sorbitol conversion of only $15.3 \%$. This result indicated that $\mathrm{La}^{3+}$ was not the main factor responsible for the high sorbitol conversion observed with $\mathrm{La}(\mathrm{OH})_{3}$. The pronounced promoting effect of $\mathrm{La}(\mathrm{OH})_{3}$ was therefore attributed to the $\mathrm{OH}^{-}$anions of $\mathrm{La}(\mathrm{OH})_{3}$. These results therefore show that $\mathrm{La}(\mathrm{OH})_{3}$ is an effective alkaline additive for enhancing the conversion of sorbitol with negligible lactic acid formation.

\subsection{Pathway for lactic acid formation in sorbitol hydrogenolysis on $\mathrm{Ni} / \mathrm{C}$ in the presence of the alkali}

The effect of reaction time on sorbitol hydrogenolysis over $\mathrm{Ni} / \mathrm{C}$ catalyst was investigated to develop a better understanding of the reaction process (Fig. 1). When $\mathrm{Ca}(\mathrm{OH})_{2}$ was used as the additive, the selectivity towards lactic acid increased from $6.8 \%$ to $8.4 \%$ over $30 \mathrm{~min}$. Furthermore, the selectivity towards glycerol gradually decreased during the first $30 \mathrm{~min}$, whilst the selectivity towards 1,2-PG increased. Further increase in the reaction time ( $>30 \mathrm{~min}$ ) did not lead to any discernible changes in the selectivity of lactic acid, glycerol, or 1,2-PG. In the case of $\mathrm{La}(\mathrm{OH})_{3}$, the selectivity towards lactic acid was about $0.1 \%$ and remained almost unchanged throughout the entire reaction. As for glycerol, its selectivity initially increased up to a reaction of $15 \mathrm{~min}$ and then gradually decreased with further increase in the reaction time. The selectivity towards 1,2-PG in the presence of $\mathrm{La}(\mathrm{OH})_{3}$ increased gradually with time, even after the sorbitol had been completely consumed.

These results showed that the selectivity profiles of the reaction towards glycerol and lactic acid were different for the $\mathrm{Ca}(\mathrm{OH})_{2}$ and $\mathrm{La}(\mathrm{OH})_{3}$ additives. To develop a deeper understanding of the underlying reasons for these differences, we investigated the reactions of glycerol under the same conditions to those used for sorbitol hydrogenolysis, and the results are shown in Table 2. In the presence of $\mathrm{Ca}(\mathrm{OH})_{2}$ (Table 2, entry 1), 1,2-PG and lactic acid were formed as the major products. The glycerol substrate was mainly converted to 1,2-PG when

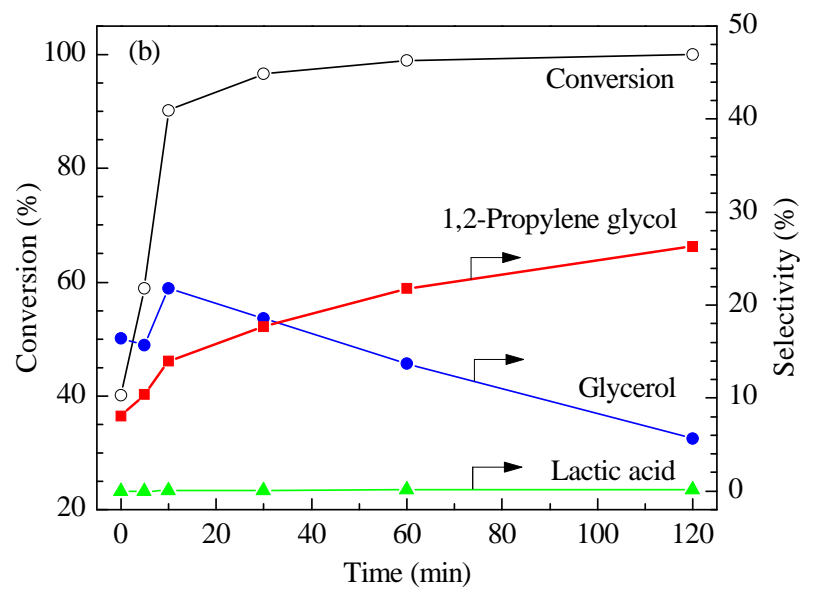

Fig. 1. Effect of the reaction time on sorbitol hydrogenolysis over $\mathrm{Ni} / \mathrm{C}$ catalyst in the presence of the different additives. (a) $\mathrm{Ca}(\mathrm{OH})_{2}$; $(\mathrm{b}) \mathrm{La}(\mathrm{OH})_{3}$. Reaction conditions: $10 \% \mathrm{Ni} / \mathrm{C} 0.3 \mathrm{~g}, \mathrm{Ca}(\mathrm{OH})_{2} 0.18 \mathrm{~g}$ or $\mathrm{La}(\mathrm{OH})_{3} 0.3 \mathrm{~g}, 10 \mathrm{wt} \%$ aqueous sorbitol solution $20 \mathrm{~mL}, 493 \mathrm{~K}, \mathrm{H}_{2}(\mathrm{RT}) 5 \mathrm{MPa}, 1 \mathrm{~h}$. 
Table 2

Conversion of glycerol and pyruvic aldehyde over $\mathrm{Ni} / \mathrm{C}$ in the presence of the additive.

\begin{tabular}{|c|c|c|c|c|c|c|c|}
\hline \multirow{2}{*}{ Entry } & \multirow{2}{*}{ Substrate } & \multirow{2}{*}{ Additive } & \multirow{2}{*}{ Conversion (\%) } & \multicolumn{4}{|c|}{ Selectivity a (\%) } \\
\hline & & & & EG & 1,2-PG & Lactic acid & Others ${ }^{b}$ \\
\hline 1 & Glycerol & $\mathrm{Ca}(\mathrm{OH})_{2}$ & 54.6 & 9.9 & 40.6 & 26.4 & 23.1 \\
\hline 2 & Glycerol & $\mathrm{La}(\mathrm{OH})_{3}$ & 62.5 & 10.7 & 54.2 & 1.0 & 34.1 \\
\hline 3 & Pyruvic aldehyde & $\mathrm{Ca}(\mathrm{OH})_{2}$ & 100 & - & 0.8 & 84.2 & 15.0 \\
\hline 4 & Pyruvic aldehyde & $\mathrm{La}(\mathrm{OH})_{3}$ & 100 & - & 35.7 & - & 64.3 \\
\hline $5^{c}$ & Pyruvic aldehyde & - & 100 & - & 31.8 & - & 68.2 \\
\hline $6^{d}$ & Pyruvic aldehyde & $\mathrm{Ca}(\mathrm{OH})_{2}$ & 100 & - & - & 85.1 & 14.9 \\
\hline $7^{\mathrm{d}}$ & Pyruvic aldehyde & $\mathrm{La}(\mathrm{OH})_{3}$ & 100 & - & - & 44.0 & 56.0 \\
\hline
\end{tabular}

Reaction conditions: $10 \% \mathrm{Ni} / \mathrm{C} 0.3 \mathrm{~g}, \mathrm{Ca}(\mathrm{OH})_{2} 0.18 \mathrm{~g}$ or $\mathrm{La}(\mathrm{OH})_{3} 0.3 \mathrm{~g}, 10 \mathrm{wt} \%$ aqueous glycerol solution or 0.05 wt $\%$ aqueous pyruvic aldehyde solution $20 \mathrm{~mL}, 493 \mathrm{~K}, \mathrm{H}_{2}$ (RT) $5 \mathrm{MPa}, 1 \mathrm{~h}$.

a C-based selectivity.

b Others include glycolic acid, acetic acid, methane, and some unidentified.

c Reaction time 5 min.

${ }^{\mathrm{d}}$ Reaction time $5 \mathrm{~min}$, without $10 \% \mathrm{Ni} / \mathrm{C}$.

$\mathrm{La}(\mathrm{OH})_{3}$ was used as an additive (Table 2, entry 2), which was consistent with the results for sorbitol hydrogenolysis. Glycerol hydrogenolysis was also conducted without the $\mathrm{Ni} / \mathrm{C}$ catalysts both in the absence and the presence of an additive $\left(\mathrm{Ca}(\mathrm{OH})_{2}\right.$ or $\left.\mathrm{La}(\mathrm{OH})_{3}\right)$, but no reaction occurred.

It has been suggested that the lactic acid produced during glycerol hydrogenolysis is formed via a pyruvic aldehyde intermediate [28]. To explore the pathway responsible for lactic acid formation in more detail, we investigated pyruvic aldehyde conversion under the same conditions as those used for sorbitol. As shown in Table 2, pyruvic aldehyde conversion in the presence of $\mathrm{Ca}(\mathrm{OH})_{2}$ (Table 2, entry 3) resulted in the formation of lactic acid as the main product, with $0.8 \%$ selectivity towards 1,2-PG. In contrast, pyruvic aldehyde conversion in the presence of $\mathrm{La}(\mathrm{OH})_{3}$ (Table 2, entry 4) resulted in the formation of 1,2-PG as the main product, with no lactic acid being detected.

To explain these differences in the selectivities of the additives towards 1,2-PG and lactic acid, we conducted three additional reactions using pyruvic aldehyde as a substrate, and the results of these reactions are shown in Table 2 (entries 5-7). When $\mathrm{Ni} / \mathrm{C}$ was used as the catalyst, pyruvic aldehyde was hydrogenated to give 1,2-PG as the main product. Furthermore, the reaction of pyruvic aldehyde only resulted in lactic acid formation when $\mathrm{Ca}(\mathrm{OH})_{2}$ or $\mathrm{La}(\mathrm{OH})_{3}$ was added to the reaction. It is noteworthy that the selectivity towards lactic acid was 0.9 -fold greater for $\mathrm{Ca}(\mathrm{OH})_{2}$ than it was for $\mathrm{La}(\mathrm{OH})_{3}$. Based on these results, we proposed a pathway for lactic acid formation starting from glycerol. According to this pathway, the hydrogenation reaction would occur on the active sites of the metal catalyst, and the rearrangement reaction would be catalyzed by the alkali. The reactions responsible for the formation of 1,2-PG and lactic acid would require different active sites, which indicates that the formation of these products would be competitive. The use of a metal catalyst in conjunction with an alkaline additive would therefore lead to different selectivities towards 1,2-PG and lactic acid, which would be dependent on the differences in the additives. For $\mathrm{Ca}(\mathrm{OH})_{2}$, which is only partially soluble in water, both the hydrogenation and rearrangement reactions would occur, resulting in the formation of 1,2-PG and lactic acid. However, for $\mathrm{La}(\mathrm{OH})_{3}$, which is largely insoluble in water, the pyruvic aldehyde substrate would be mainly converted to 1,2-PG through a hydrogenation reaction.

Fig. 2 shows the relationship between the selectivity ratio of $S$ (lactic acid) to $S(1,2-\mathrm{PG})$ and the mass ratio of $\mathrm{Ca}(\mathrm{OH})_{2}$ to sorbitol for the hydrogenolysis reactions of sorbitol, which were calculated using the data in Table 1 (entries 3-7). The selectivity ratio of $S$ (lactic acid) to $S(1,2-\mathrm{PG})$ increased as the amount of $\mathrm{Ca}(\mathrm{OH})_{2}$ added to the reaction increased. These results also indicated that the reactions responsible for the formation of 1,2-PG and lactic acid were competitive. More alkali was favorable for lactic acid formation.

Based on the above results, we proposed a pathway for lactic acid formation during sorbitol hydrogenolysis over $\mathrm{Ni} / \mathrm{C}$ in the presence of an alkaline additive, which is shown in Scheme 1. Given that a pathway for sorbitol hydrogenolysis has already been reported in the literature, we have focused primarily on the pathway responsible for lactic acid formation during this reaction. Pyruvic aldehyde would be formed as an intermediate during the course of this reaction and subsequently converted to lactic acid via a rearrangement reaction. Pyruvic aldehyde could also be converted to 1,2-PG through a hydrogenation reaction. The addition of different additives would lead to different selectivities towards lactic acid. For example, the addition of $\mathrm{Ca}(\mathrm{OH})_{2}$ would lead to the hydrogenation and rear-

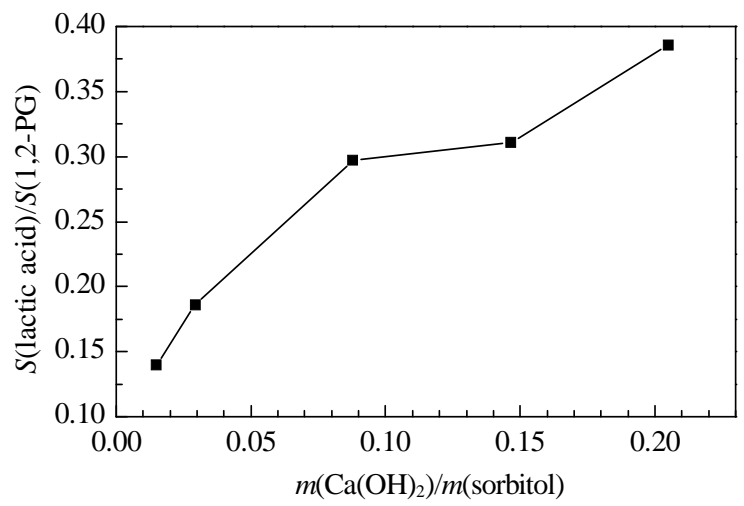

Fig. 2. Effect of the mass ratio of $\mathrm{Ca}(\mathrm{OH})_{2}$ to sorbitol on the ratio of $S$ (lactic acid) to $S(1,2-\mathrm{PG})$ during sorbitol hydrogenolysis over $\mathrm{Ni} / \mathrm{C}$ catalyst. These results were calculated using the data in Table 1 (entries 3-7). 


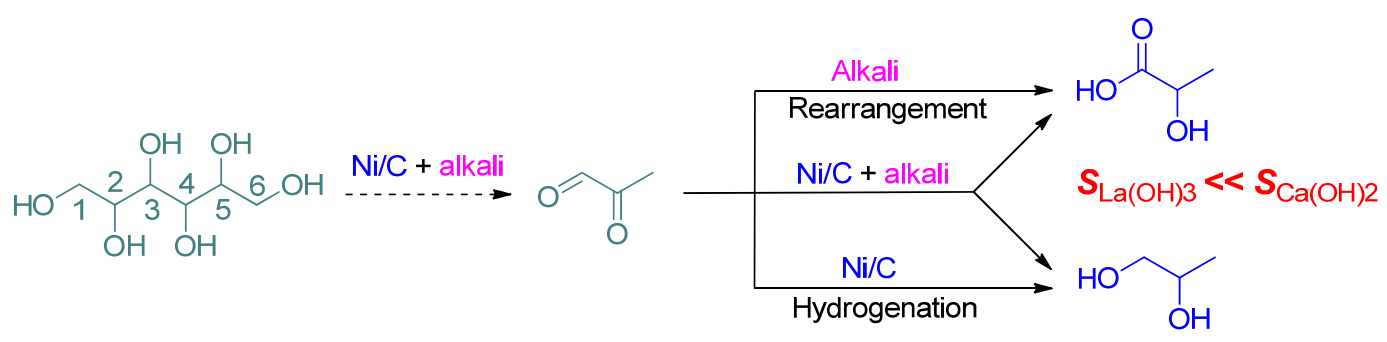

Scheme 1. Proposed pathway for lactic acid formation via sorbitol hydrogenolysis over Ni/C catalyst in the presence of an alkaline additive.

rangement reactions, whilst the addition of $\mathrm{La}(\mathrm{OH})_{3}$ would favor the hydrogenation reaction as the major pathway, leading to only trace quantities of lactic acid.

\section{Conclusions}

The total selectivity of the hydrogenolysis reaction of sorbitol towards $\mathrm{C} 2$ and $\mathrm{C} 4$ products was enhanced by the presence of $\mathrm{La}(\mathrm{OH})_{3}$. Furthermore, the addition of $\mathrm{La}(\mathrm{OH})_{3}$ resulted in a sorbitol conversion of $99 \%$ with only trace quantities of lactic acid being detected. In contrast, the use of $\mathrm{Ca}(\mathrm{OH})_{2}$ as an additive led to an increase in the selectivity towards C3 products, which was most likely be related to the formation of higher levels of lactic acid. Pyruvic aldehyde, which is formed as an intermediate during sorbitol hydrogenolysis, was converted to 1,2-propylene glycol and lactic acid via hydrogenation and rearrangement reactions, respectively. We found that these two reactions were competitive and that the hydrogenation reaction became the dominant transformation in the presence of $\mathrm{La}(\mathrm{OH})_{3}$. These results are therefore of fundamental importance in terms of enhancing our understanding of sugar alcohols hydrogenolysis and the production of lactic acid.

\section{References}

[1] A. M. Ruppert, K. Weinberg, R. Palkovits, Angew. Chem. Int. Ed., 2012, 51, 2564.
[2] W. P. Deng, M. Liu, X. S. Tan, Q. H .Zhang, Y. Wang, J. Catal., 2010, $271,22$.

[3] S. Saravanamurugan, A. Riisager, ChemCatChem, 2013, 5, 1754.

[4] D. K. Sohounloue, C. Montassier, J. Barbier, React. Kinet. Catal. Lett., 1983, 22, 391.

[5] M. Banu, P. Venuvanalingam, R. Shanmugam, B. Viswanathan, S. Sivasanker, Top. Catal., 2012, 55, 897.

[6] I. M. Leo, M. L. Granados, J. L. G. Fierro, R. Mariscal, Chin. J. Catal., 2014, 35, 614

[7] L. M. Ye, X. P. Duan, H. Q. Lin, Y. Z. Yuan, Catal. Today, 2012, 183, 65.

[8] X. G. Chen, X. C. Wang, S. X. Yao, X. D. Mu, Catal. Commun., 2013, 39, 86.

[9] L. Zhao, J. H. Zhou, Z. J. Sui, X. G. Zhou, Chem. Eng. Sci., 2010, 65, 30.

[10] K. Y. Wang, M. C. Hawley, T. D. Furney, Ind. Eng. Chem. Res., 1995, $34,3766$.

[11] J. Y. Sun, H. C. Liu, Green Chem., 2011, 13, 135.

[12] I. Clark, Ind. Eng. Chem., 1958, 50, 1125.

[13] J. Y. Sun, H. C. Liu, Catal. Today, 2014, 234, 75.

[14] M. Banu, S. Sivasanker, T. M. Sankaranarayanan, P. Venuvanalingam, Catal. Commun., 2011, 12, 673.

[15] T. A. Werpy, J. G. Frye, A. H. Zacher, D. J. Miller, US Patent 0130545.2003.

[16] F. Auneau, M. Berchu, G. Aubert, C. Pinel, M. Besson, D. Todaro, M. Bernardi, T. Ponsetti, R. Di Felice, Catal. Today, 2014, 234, 100.

[17] J. H. Zhou, M. G Zhang, L. Zhao, P. Li, X. G. Zhou, W. K. Yuan, Catal. Today, 2009, 147, S225.

[18] L. Zhao, J. H. Zhou, H. Chen, M. G. Zhang, Z. J. Sui, X. G. Zhou, Korean

\section{Graphical Abstract}

Chin. J. Catal., 2016, 37: 177-183 doi: 10.1016/S1872-2067(15)60976-7

Effects of alkaline additives on the formation of lactic acid in sorbitol hydrogenolysis over $\mathrm{Ni} / \mathrm{C}$ catalyst

Junjie Zhang, Fang Lu*, Weiqiang Yu, Rui Lu, Jie Xu *

Dalian Institute of Chemical Physics, Chinese Academy of Sciences; University of Chinese Academy of Sciences

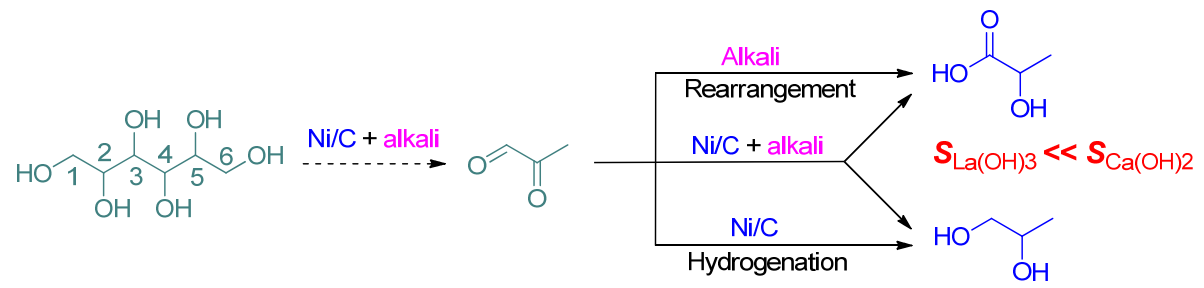

$\mathrm{La}(\mathrm{OH})_{3}$ has been identified as an efficient additive for sorbitol hydrogenolysis over Ni/C with very little lactic acid formation. The pathways for 1,2-propylene glycol and lactic acid formation were competitive, with the hydrogenation to 1,2-propylene glycol dominating for $\mathrm{La}(\mathrm{OH})_{3}$. 
J. Chem. Eng., 2010, 27, 1412.

[19] J. H. Zhou, G. C. Liu, Z. J. Sui, X. G. Zhou, W. K. Yuan, Chin. J. Catal., 2014, 35, 692.

[20] T. Soták, T. Schmidt, M. Hronec, Appl. Catal. A, 2013, 459, 26.

[21] Z. W. Huang, J. Chen, Y. Q. Jia, H. L. Liu, C. G .Xia, H. C. Liu, Appl. Catal. B, 2014, 147, 377.

[22] J. J. Zhang, F. Lu, W. Q. Yu, J. Z. Chen, S. Chen, J. Gao, J. Xu, Catal. Today, 2014, 234, 107.

[23] W. Q. Yu, F. Lu, Y. L. Yang, J. J. Zhang, J. Gao, F. Wang, J. Xu, Energy
Environ. Focus, 2012, 1, 99.

[24] B. P. Gangwar, V. Palakollu, A. Singh, S. Kanvah, S. Sharma, RSC Adv., 2014, 4, 55407.

[25] R. Y. Sun, T. T. Wang, M. Y. Zheng, W. Q. Deng, J. F. Pang, A. Q. Wang, X. D. Wang, T. Zhang, ACS Catal., 2015, 5, 874.

[26] Z. G. Zhang, J. E. Jackson, D. J. Miller, Ind. Eng. Chem. Res., 2002, 41, 691.

[27] Z. G. Zhang, J. E. Jackson, D. J. Miller, Appl. Catal. A, 2001, 219, 89.

[28] E. P. Maris, R. J. Davis, J. Catal., 2007, 249, 328.

\title{
$\mathrm{Ni} / \mathrm{C}$ 催化剂上山梨醇氢解反应中碱对乳酸形成的影响
}

\author{
张俊杰 ${ }^{\mathrm{a}, \mathrm{b}}$, 路 芳 ${ }^{\mathrm{a}, \# \text {, 于维强 }}{ }^{\mathrm{a}}$, 卢 锐 ${ }^{\mathrm{a}, \mathrm{b}}$, 徐 杰, \\ a 中国科学院大连化学物理研究所催化基础国家重点实验室, 洁净能源国家实验室(筹), 辽宁大连116023 \\ ${ }^{\mathrm{b}}$ 中国科学院大学, 北京 100049
}

摘要: 山梨醇是重要的生物基平台化合物, 其选择加氢裂解制备乙二醇和 1,2 -丙二醇等低碳二元醇, 是一个具有重要科学 意义和应用前景的催化过程. 山梨醇氢解反应涉及C-C键和C-O键等化学键的裂解, 裂解选择性尤为关键. 通常情况下, 添 加 $\mathrm{NaOH}, \mathrm{KOH}, \mathrm{Ca}(\mathrm{OH})_{2}, \mathrm{CaO}$ 和 $\mathrm{Ba}(\mathrm{OH})_{2}$ 等碱性物质可增加糖醇转化率和二元醇选择性, 但也会生成大量乳酸等副产物. 研究乳酸的生成途径, 探索抑制乳酸生成的方法, 对于提高山梨醇加氢裂解制备低碳二元醇的选择性具有重要意义.

本文以 Ni/C催化剂上山梨醇加氢裂解反应为模型反应, 研究了碱性化合物添加剂类型及其用量对乳酸生成的影响. 根 据加氢裂解机理分析可知, 糖醇氢解主要涉及以下关键步骤: 在碱的存在下, 多元醇在金属催化剂上发生脱氢反应生成相 应的羰基中间体; 然后, 羰基中间体在碱性介质中通过逆羟醛缩合反应, 发生 $\mathrm{C}-\mathrm{C}$ 键断裂. 因此, 在糖醇氢解反应和 $\mathrm{C}-\mathrm{C}$ 键 断裂中, 添加碱性化合物将会不可避免地生成乳酸.

结果表明, 以 $\mathrm{NaOH}$ 和 $\mathrm{Ca}(\mathrm{OH})_{2}$ 为添加剂时, 山梨醇加氢裂解生成乳酸的选择性分别为 $15.1 \%$ 和 $8.9 \%$. 而以 $\mathrm{La}(\mathrm{OH})_{3}$ 为添 加剂时, 生成乳酸的选择性仅为 $0.1 \%$. 以 $\mathrm{Ca}(\mathrm{OH})_{2}$ 和 $\mathrm{La}(\mathrm{OH})_{3}$ 为添加剂时反应具有高活性, 山梨醇转化率均可达到 $99 \%$ 以上. 分别以 $\mathrm{Ca}(\mathrm{OH})_{2}$ 和 $\mathrm{La}(\mathrm{OH})_{3}$ 为添加剂, 研究了碱性添加剂用量对山梨醇氢解反应的影响. 结果表明, 以 $\mathrm{Ca}(\mathrm{OH})_{2}$ 为添加剂时, 山梨醇转化率和乳酸选择性均随着 $\mathrm{Ca}(\mathrm{OH})_{2}$ 用量增加而增加; 当 $\mathrm{OH}^{-}$投料量为 $11.06 \mathrm{mmol}$ 时, 乳酸选择性可达 $11.7 \%$. 而以 $\mathrm{La}(\mathrm{OH})_{3}$ 为添加剂时, 即使 $\mathrm{La}(\mathrm{OH})_{3}$ 用量仅为 $0.08 \mathrm{mmol}$ 时, 山梨醇转化率也可高达 $99 \%$; 继续增加 $\mathrm{La}(\mathrm{OH})_{3}$ 用量, 对乳酸的选 择性影响不大; 当 $\mathrm{OH}^{-}$投料量为 $11.06 \mathrm{mmol}$ 时, 乳酸选择性也只有 $0.3 \%$.

对山梨醇加氢裂解反应分析可知, 与 $\mathrm{Ca}(\mathrm{OH})_{2}$ 相比, $\mathrm{La}(\mathrm{OH})_{3}$ 添加剂可使 $\mathrm{C} 2$ 和 $\mathrm{C} 4$ 产物的总选择性从 $20.0 \%$ 增加到 $24.5 \%$. 上述结果表明 $\mathrm{La}(\mathrm{OH})_{3}$ 可高效促进山梨醇加氢转化. 为了探索 $\mathrm{Ca}(\mathrm{OH})_{2}$ 或 $\mathrm{La}(\mathrm{OH})_{3}$ 为添加剂时山梨醇加氢裂解产物分布不 同的本质原因, 以 Ni/C催化剂催化的丙酮醛加氢转化为探针反应, 探讨了乳酸形成的可能路径. 结果表明, 丙酮醛可能是山 梨醇氢解反应的关键中间体之一. 在仅以 $\mathrm{Ni} / \mathrm{C}$ 催化加氢时, 丙酮醛容易被转化为 1,2 -丙二醇; 当只存在碱性添加剂时, 丙酮 醛可发生重排并被转化为乳酸主产物, 这可能是乳酸生成的主要原因. 进一步研究表明, 以 $\mathrm{Ca}(\mathrm{OH})_{2}$ 为添加剂时, 乳酸选择 性是以 $\mathrm{La}(\mathrm{OH})_{3}$ 为添加剂时的1.9倍. 在 $\mathrm{Ni} / \mathrm{C}$ 催化剂和碱性添加剂共存时, 由于碱性添加剂的区别, 则会得到不同选择性的 1,2-丙二醇和乳酸. 结果表明, 通过丙酮醛催化加氢可得到1,2-丙二醇, 也可以通过重排反应生成乳酸; 这两类反应是竞争 性的. 在山梨醇氢解反应中, 以 $\mathrm{Ca}(\mathrm{OH})_{2}$ 为添加剂时, 加氢反应和重排反应均可发生. 而以 $\mathrm{La}(\mathrm{OH})_{3}$ 为添加剂时, 丙酮醛加氢 反应占主导, 仅生成微量乳酸. 该研究对提高山梨醇催化加氢裂解选择性具有参考意义.

关键词: 乳酸; 碱; 山梨醇; 催化氢解; 镍催化剂

收稿日期: 2015-08-28. 接受日期: 2015-09-24. 出版日期: 2016-01-05.

*通讯联系人. 电话/传真: (0411)84379245; 电子信箱: xujie@dicp.ac.cn

\#通讯联系人. 电话/传真: (0411)84379245; 电子信箱: lufang@dicp.ac.cn

基金来源：国家自然科学基金(21203183, 21233008, 21473188).

本文的英文电子版由Elsevier出版社在ScienceDirect上出版(http://www.sciencedirect.com/science/journal/18722067). 